\title{
Models and scenarios of the Neolithic in Central Europe
}

\author{
Ivan Pavlů \\ Institute of Archaeology CAS CR, Prague, CZ \\ pavlu@arup.cas.cz
}

\begin{abstract}
The Neolithic in Central Europe can no longer be characterised as comprising a compact population of a single society in which organisations and subsistence strategies were homogeneous. Despite the apparent uniformity of the pottery, the period was characterised by a mosaic of small communities that differed in both economic and social organisation for almost two millennia. These genetically diverse communities inhabited geographical spaces of varying size, from regions to micro-regions to single settlements. The polymorphous modes of exploiting natural resources ensured successful long-term survival, even when the results of the emerging farming economy were uncertain and unreliable in some groups.
\end{abstract}

IZVLEČEK - Srednjeevropskega neolitika ni več mogoče povezovati z enovito populacijo in homogeno organizirano družbo z enotno strategijo preživetja. Kljub navidezni uniformnosti lončarskih produkcij, so se v času skoraj dveh tisočletji oblikovale majhne skupnostih, ki so se razlikovale tako $v$ družbeni ureditvi kot gospodarskih strategijah. Genetsko različne skupine so bile naseljene v prostorih različnih velikosti, od regije in mikro regije do posameznega naselja. Mnogolična izraba naravnih virov je zagotavljala dolgoročno preživetje, tudi takrat, ko so bili učinki razvijajočega se kmetovanja negotovi.

KEY WORDS - Central Europe; Neolithisation; Bohemia; palaeoeconomy; settlement patterns

\section{The cultural-historical model}

In the latter half of the $20^{\text {th }}$ century, synthetic work on the origin and development of the Neolithic in Central Europe was based on the idea that the spread of the Neolithic lifestyle was connected with the migration of people from regions which had already undergone Neolithisation - the notion of demic diffusion - proceeding through several successive stages from the Near East to Anatolia and the Aegean, and then in two directions, north to the Carpathian Basin and west to the Mediterranean. Before 5500 calBC, in northern Transdanubia, the early Starčevo Culture, perhaps under the influence of the emerging Vinča Culture, gradually transformed into the earliest Linear Pottery Culture, which then spread further to north-western and eastern Europe: "From centres in Transdanubia and lower Austria, the LBP began to expand into the loess territories of the central European uplands" (Kaczanowska, Kozłowski 2003.245).

In the 1980s, these basic theses were further supported by anthropological research (Vencl 1982. 650), which confirmed a general trend of migrations along the diagonal south-east-north-west axis through Europe. As early as the 1970s, gradual improvements in genetic studies of European populations led to the creation of a model known today as the wave-of-advance (Ammerman, Cavalli-Sforza 1984). The aim of this model was to provide an alternative to older theories that posited an autochthonous origin for the European Neolithic, which were based on structural-anthropological concepts and linked to the nationalism of the mid-20th century ( $\mathrm{Am}$ merman 2003.13). However, today's palaeogenetic 
research can be seen from the distance as having its own problems that could affect the archaeological theories derived from it (Cavalli-Sforza 2003.302306).

Most cultural-historical concepts explicitly or implicitly included the idea that Neolithic cultures are identifiable with certain population groups with distinctive pottery who moved through Europe, carrying the Neolithic with them. Because archaeological evidence of older settlements is scarce, it was assumed that these Neolithic groups expanded into territories abandoned by the previous populations, where they laid the foundations of, for example, a new cultural landscape. These theories of Neolithisation had their own inner logic, did not contradict modern ideas of prehistoric society, and were in accord with the prevalent concept of a progressive linear development that led directly to later historical entities in Europe.

The cultural-historical model of the origin and development of Central European Neolithic society can be compared with the geographical-cultural model of Epipalaeolithic development in the Levant, which led to the emergence of a Neolithic society in the Natufian period. This model was developed over a long period by the Lyon School (Aurenche et al. 1981) and can be divided into four steps: (i) the discovery and geographical location of prehistoric cultures in a given period, (ii) a finer categorisation of cultural groups, (iii) the drawing out proposal of a hierarchy of these groups by comparing their content and determining centres of evolution, and (iv) observing the changing geographical location of these centres over a given period (Delage 2004.105). This model has been debated, and its historical core is believed to be rooted in the philosophical tradition of the European Enlightenment. The evolutionary progressbased view of history included the idea that history is an unequivocal process heading towards the improvement of the human condition, which is measurable by intellectual and political maturity and technical progress.

Applied to archaeology, the criticism of such a concept of history consists of rejecting all notions of history as a gradual and linear development towards a predictable future. Therefore, today's archaeological work questions interpretations that state that "traits (architecture, pottery, domesticated animals and plants, life in villages etc.) once invented and found valuable in reference to modern Western Civilization will always be kept and passed from one generation to another ... and from one civilisation to another" (Delage 2004.106). It then becomes quite ineffective to explore and describe Neolithic society either in ethnographic terms used for pre-state rural societies, or contemporary terms such as trade, contacts, mobility and hierarchy. It is more desirable to explore the socio-economic conditions of group identities, which would lead to the reconstruction of Neolithic communities identifiable by house or gender particularities, or by local and regional strategies for creating social groups (Asouti 2006.106). In this respect, the mobilisation and intensification of the entire network of relations between individual elements of Neolithic society play an important role. Temporal and spatial changes in social conditions, together with their local manifestations, could have become the basis for a complete reconstruction of social organisation in the Neolithic, although little of the research on Neolithic settlements seems useful so far.

In the separate spheres model of the aceramic Neolithic (Fig. 1), which shows a division of the Levant into regions of farmers, herders and hunters (BarYosef 2002), the cultural-historical concept meets the socially-defined division of territory. It proves impossible to abandon entirely the archaeological classification of regions based on morphological comparisons of different artefact types, and replace this with a purely socio-economic classification, because the archaeological method does not permit this. On the one hand, contemporary anthropological models offer no guidance for studying the Neolithic (Perlés 2001.305). On the other hand, all reflections on the social organisation of the Neolithic, as opposed to later hierarchical societies, are essentially based on interpretations of the available cultural-geographical classifications of Neolithic architecture and rituals (Kuijt 2000.315).

Reflections of this kind must necessarily rely on visible archaeological artefacts, as is well documented by the elaborate interpretations of long-distance trade in, and barter with, obsidian and other raw materials needed in the chipped stone industry. This is true of the Near East (Asouti 2006.102-104), the Aegean (Perlés 2001; Tangri 1989; Runnels 1989; Halstead 1999) and the Carpathian Basin (Mateiciucová, Matecka-Kukawka 2007; Whittle 1996). The generalising nature of archaeological finds first the chipped stone industry, then pottery - does not permit the identification of real social groups. Rather, it creates an illusory classification of space and creates an impression of uniformity, thus con- 


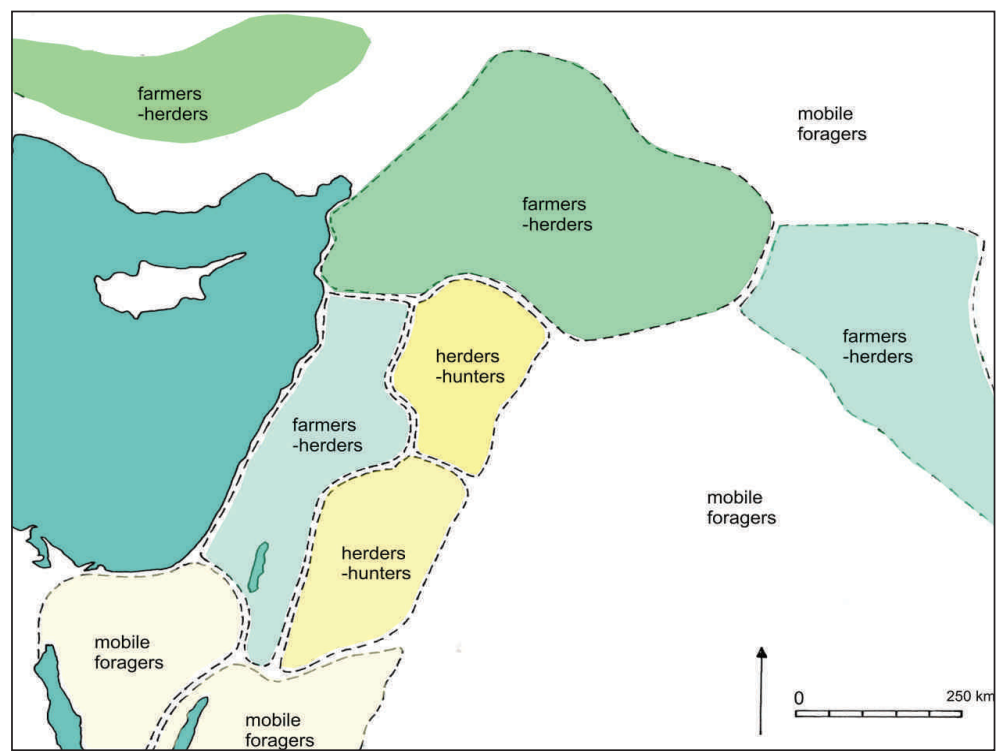

Fig. 1. Near East. Pre-pottery spheres model (after Bar-Yosef 2002; Asouti 2006).

cealing the subtleties of the social identities of the populations.

\section{The Bohemian scenarion in the context of Cen- tral Europe}

Let us assume that the original population of Bohemia did not disappear, as has been thought previously, but that Neolithisation was the result of longterm contacts between the original population and inhabitants of regions already Neolithicised, such as the Carpathian Basin. Anthropologists distinguish between at least two stages of such contact. The first stage is mere exchange in the social sphere; the second is a change of system for economic reasons (Verhart, Wansleeben 1997.66). Applying this view, the earliest Linear Pottery occurred in the second stage of contact. In Bohemia, this dates to around $5700 / 5500$ calBC, which means that the first stage must have occurred before that time, although so far this has been undetectable and indiscernible by archaeological means. If this is the case, the original Mesolithic society must have become differentiated between 6000 and 5500 calBC, creating socio-economically distinct spheres among the original populations (Fig. 2). The original hunter-gatherer society then survived only in regions unsuitable for farming, which the cultural-historical model also conceded (Vencl 1982.654).

The first Neolithic population did not carry out a large-scale and continuous colonisation of a new type of landscape, but rather seized a small number of isolated optimal locations, as is evident in the Polish lowlands until the $3^{\text {rd }}$ millennium $\mathrm{BC}$ (Nowak 2009.451-461). The synchronous density of settlements at the beginning of the earliest Linear Pottery phase was substantially lower than a complete map of the Neolithic population shows. The relatively rapid occupation of the main areas suitable for farming used to be considered as evidence of rapid and massive colonisation. However, the low density of the initial settlements might also have reflected the low density of the previous population (Pavlì, Květina 2008). Pre-farming populations were much more scattered than settled populations. However, because of their greater mobility, hunter-gatherers, populations used larger areas. Therefore, at the time when the first groups started to settle in permanent houses, only a few locations within a large area were settled.

It is my opinion that the original population partly transformed into a new population of farmers and partly moved into areas less suitable for farming. The border between the Mesolithic and the Neolithic is not a clear-cut line in a region, but rather a mosaic of regions with different kinds of populations. This is because different groups of the original population reacted differently to contact with the neighbouring Neolithicised populations of Moravia and the Carpathian Basin. Comparing the scope of the earliest Linear Pottery localities with that of all the Mesolithic localities reveals a clear geographical division of Bohemia into groups of localities that can be interpreted as settlements of newly arrived farmers, or of mobile hunter-gatherers, or possibly even of the first herders (see Vencl 2007.80 for a different interpretation). Around $5500 \mathrm{calBC}$, farming groups occupied territories in eastern and northwestern Bohemia and smaller regions in central and south-western Bohemia. The hunter-gatherer groups were remnants of the domestic population who had not adopted the settled lifestyle and retained their subsistence strategies in areas unsuitable for the first farmers. The herder groups can be interpreted as that portion of the original population of northern (Š́da 2007) and eastern Bohemia who adopted only cattle breeding from the Neolithic lifestyle, thus creating the first herder communities, of a sort. This interpretation offers a wider socio-economic picture of the $6^{\text {th }}$ millennium BC. 
It is also my opinion that a scenario of scattered population groups with different economic structures is more acceptable for the Czech area than the hitherto prevalent idea of cultural and economic uniformity. The co-existence of social groups with different modes of production is accepted today in the Near East, from the Epipalaeolithic until the beginning of the ceramic Neolithic. Even with reference to European regions, this model is probably the most acceptable, although it is still difficult to prove by archaeological means. Throughout the entire Central European Neolithic, the ratio of the original population to the Neolithicised newcomers changed constantly. It is impossible to rule out that small groups, comprising one or

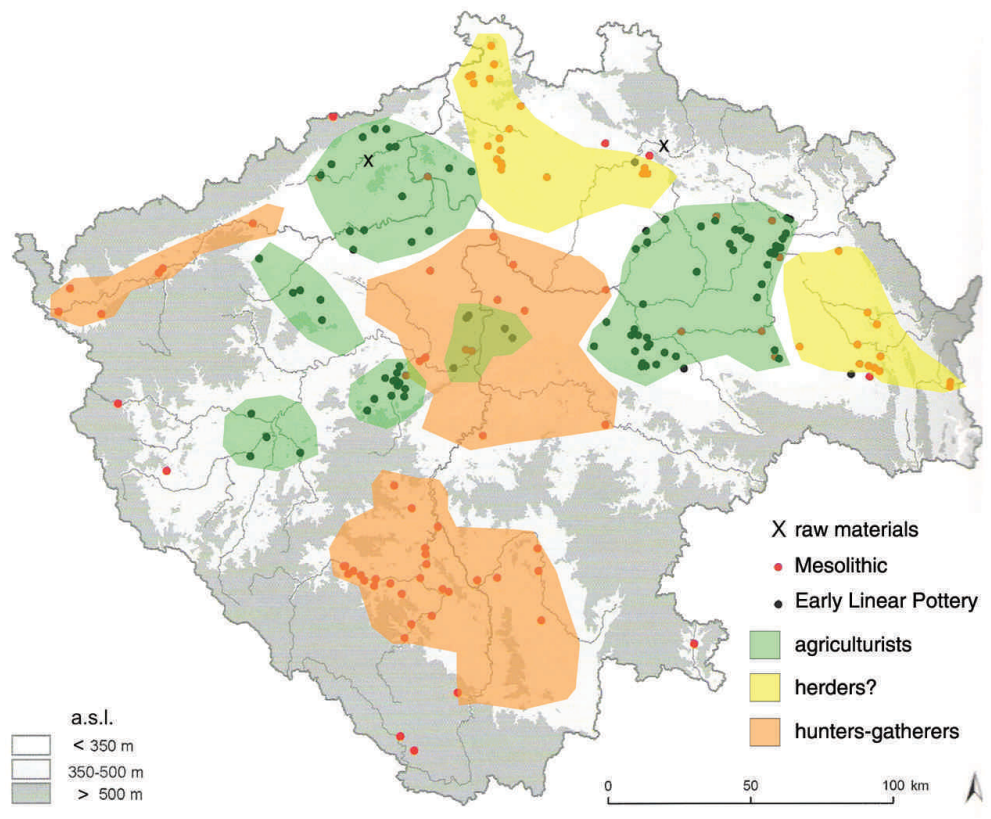

Fig. 2. The reconstruction of Bohemian spheres at 6000-5500 calBC (after Pavlů 2011). two families, were arriving from distant territories not as colonists or ambassadors of a new means of subsistence, but as part of the general mobility of that time. The demographic processes are mirrored indirectly in the development of active decorative styles of Linear Pottery, and later Stroked Pottery, which are observable both qualitatively and quantitatively. However, throughout the entire Neolithic period of approximately 1400 years $(5700 / 5500-$ $4300 \mathrm{calBC}$ ), it is also impossible to rule out a resurgence for some reason of the social influence of the original population (Pavli̊, Květina 2008). These changes might have been the background to further stages in the development of Central European society, both in its beginnings and later.

It is generally assumed that the demographic composition of the newly emerging Neolithic population incorporated some parts of the original population, especially women, as evidenced by analyses of late Linear burial sites (Price, Bentley 2005.211). Women, being important agents and participants in social activities, which undoubtedly included pottery making, inevitably carried their cultural characteristics into the Neolithicised society. Pottery decoration in general might have been one of these characteristics. Because in many regions and many developmental stages Neolithic symbolism was a continuation of an older symbolism, it is still hard to tell which elements of the decorative symbolism in Linear Pottery are pre-Neolithic. Therefore, a disrupted style in pottery decoration might reveal not only chronology (Čižmár 1998.135) but also the influ- ence of women from the original population who lived in Neolithicised groups.

I think it is most likely that the intensity of the original influence varied throughout the Neolithic. During the development of the Linear Pottery Culture, its social significance in the new system was weak, until it gained strength towards the end in the Šarka type. The ensuing cultural change, giving rise to Stroked Pottery Culture, brought a new stylistic concept of pottery decoration that abandoned the richly structured ornamentation of Linear Pottery. This, in a sense, was a return to the older, pre-Neolithic, stylistic concept of a passive style of ornament. The same can be said about settlement changes. A good example is the now classic find of a Neolithic house in Stvolínky (Zápotocká 1999), which was first thought to indicate a late colonisation of a territory which had not undergone Neolithisation. However, assuming that groups of hunters or herders had been using the territory for a long period before, the Stvolínky house can be explained as the first archaeologically visible evidence of such a group founding a settlement.

\section{Types of settlement}

The overall situation of the Neolithic in Central Europe, represented by the earliest Linear Pottery around 5700/5500 calBC and its continuation until around 4000 calBC, can no longer be viewed as being characterised by a compact population of a single society in which organisations and subsistence 
strategies were homogeneous. A more detailed exploration of its archaeological content shows clearly, despite the apparent uniformity of the pottery, that it consisted of a mosaic of small communities with differences in both economic and social organisation for almost two millennia. These genetically diverse communities inhabited geographical spaces of varying size, from regions to micro-regions to single settlements. Even their interrelations were necessarily diverse, from mutual independence to various degrees of co-operation, to cope with local hostility, competition and enmity. An eclectic approach to using natural resources ensured successful long-term survival even when the results of the emerging farming economy were uncertain and unreliable in some groups.

The basic unit of Neolithic society remained the house, or household, inhabited by one or two families, as confirmed by the fact that the central areas of houses in Bylany are either single or double (Modderman 1986). According to Pieter Van de Velde (1979; 1990; 2007.238), houses could be grouped into yards or wards, which are larger economic units within a settlement. It is generally agreed that the layout of Neolithic settlements was determined by the principles of a social order, whether or not the form and details of the order are known to us. A yard organisation is believed to have existed at the settlements of the Aldenhoven Plateau (Lüning 2005), where this model serves as a basis for a detailed chronology of the settlements (Stehli 1988; Stäuble 2005). The theoretical division of houses is demonstrated by the example of the Geelen JKV site in the Netherlands. Here, the chronology relies less on pottery and more on the developmental typology of the interior structure of the central areas within houses (Van de Velde 2007). In Bylany, no such grouping into higher units has been observed, which is why its chronology is based exclusively on pottery analysis (Pavli 2011). The assumed genealogy of houses, as demonstrated above regarding supplementary ornamentation, does not delineate any longterm housing space.

The existence of a single dominant person cannot be assumed, since it is not supported by any evidence from the settlements and burial sites. It is more likely that there were many individuals, both men and women, who for various reasons enjoyed a higher social status in a settlement formed by a co-operating group of houses. In Bylany, large houses with special architecture (Soudsky 1966), which have been observed only in periods with an exception- ally high number of houses, could have served as the short-term residence of the leading family who organised the co-operation of the many inhabitants. This house might have hosted various social events and ceremonies that otherwise took place outdoors, if at all. This leads us to the conclusion that, throughout the development of a larger settlement area, such as Bylany in the Linear Pottery era, no longterm stable social structures were created to perform functions at a level higher than that of houses and families. This brings us back to the idea of the relative social self-sufficiency and independence of basic family units. Of course, these primary social units would have engaged in necessary economic co-operation, probably based on kinship ties, either real or mythical.

The existence of an even higher level of social organisation is sometimes inferred from the configuration of settlements within an entire region. There are two extreme variants of such a configuration. The first is a row in which settlements of varying size and importance form a string along a watercourse (Modderman 1986), with settlements usually $1 \mathrm{~km}$ apart, or more widely spaced, with settlements approximately $5 \mathrm{~km}$ apart (Coudart 1998. 25). The watercourse serves as a natural communication route. The second is a network where settlements are distributed throughout the entire region across the natural network of watercourses. Among other things, this network can provide a basis for exploring multilateral social relations (Classen 2005.122). In both variants, there is a hierarchy of large settlements, small settlements and solitary houses, although these are chronologically diverse. The network model gives rise to the idea of a socio-economic hierarchy that is bound to a certain centralised activity, usually the acquisition and distribution of an important raw material or goods (Zimmermann 1995; Kneipp 1998). In addition to these configurations, there is also the nuclear family arrangement (Petrasch 2003.512), for which there is evidence at the large settlements of the Kutná Hora region (Pavli, Rulf 1996; Pavli 2005) (Fig. 3.). This might correspond to the idea of two exogamous groups of inhabitants related by moiety. Van de Velde (2007. 237) interprets two parts of the Geelen-JKV site in a similar way.

The creation of parent and child settlements can be dated back to the first colonisation (Petrasch 2003), provided that we apply the older model of a single colonisation wave populating the whole of Central Europe with the Linear Pottery culture over a short 
period (Frirdich 2005). Relations with the original inhabitants might have been mirrored, on the one hand, in the territorial distribution of the oldest Linear Pottery settlements, and, on the other hand, in the methods of co-operation and limits of competence of various subsistence strategies (Frirdich 2005.102). It is also necessary to take into account the varying degrees of mobility of individual communities and, above all, the varying degrees of their co-existence and integration. It could be assumed that the original inhabitants who did not adopt settled farming retreated to regions such as southern Bohemia that suited their own lifestyle, but were unsuitable for farmers. However, it is impossible to rule out co-existence and close co-operation within a single site. If that were the case, several distinct groups would have created their own autonomous neighbourhoods, distinguishable only by the types of animal bone, for example, but using the same kind of pottery, as at Cuiry-lès-Chaudardes (Hachem 1994). It is uncertain whether the farming, herding and hunting families were even more closely integrated at the level of houses within a settlement. An interpretation of different Linear Pottery house types, analogous to that of circular and rectangular houses in the Levant (Verhoeven 1999.214), stating that

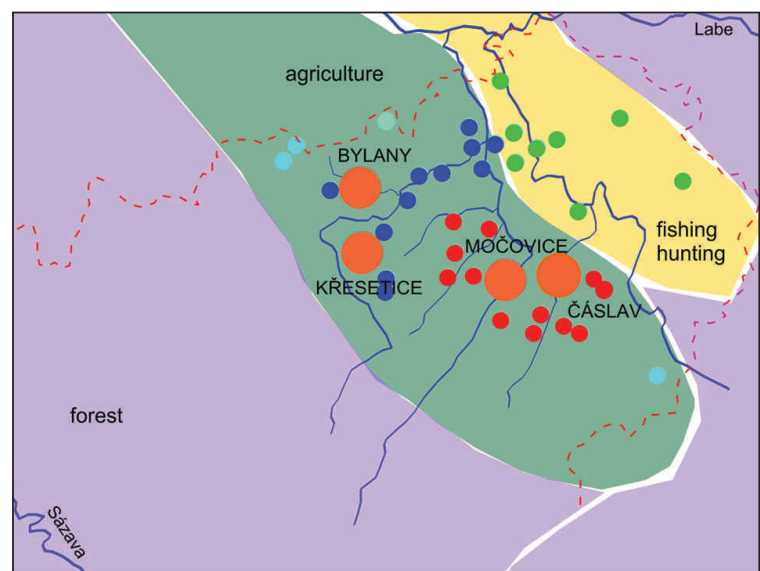

Fig. 3. Kutná Hora region. Interpretation of the different economic-social sub-regions (after Pavlů 2011).

three-part houses were inhabited by farmers, twopart houses by herders and single-part houses by hunters-gatherers, remains only a hypothesis for future consideration.

\section{ACKNOWLEDGEMENTS}

This paper was supported by fund GAAV IAA800020701.

\section{References}

Ammerman A. J. 2003. Looking Back. In A. J. Ammerman, P. Biagi (eds.), The Widening Harvest. The Neolithic Transition in Europe: Looking Back, Looking Forward. Archaeological Institute of America, Boston: 3-23.

Ammerman A. J., Cavalli-Sforza L. L. 1984. The Neolithic Transition and the Genetics of Populations in Europe. Princeton University Press. Princeton.

Asouti E. 2006. Beyond the Pre-Pottery Neolithic B interaction sphere. Journal of World Prehistory 20: 87-126.

Aurenche 0., Cauvin J., Cauvin M.-C., Copeland L., Hours F. and Sanlaville P. 1981. Chronologie et organisation de l'espace dans le Proche Orient de 12000 a 5600 avant J. C. In J. Cauvin, P. Sanlaville (eds.), Prehistoire du Levant: chronologie et organisation de l'espace depuis les origines jusqu'au VIe millenaire. Lyon, Maison de l'Orient mediterraneen, 10-14 juin 1980. Colloques internationaux du Centre national de la recherche scientifique, no 598. Editions du Centre national de la recherche scientifique, Paris: 571-603.
Bar-Yosef 0. 2002. The Natufian culture and the early Neolithic: social and economic trends in Southwest Asia. In P. Bellwood, C. Renfrew (eds.), Examining the farming/language dispersal hypothesis. McDonald Institute for Archaeological Research, Cambridge: 113-126.

Cavalli-Sforza L. L. 2003. Returning to the Neolithic Transition in Europe. In A. J. Ammerman, P. Biagi (eds.), The Widening Harvest. The Neolithic Transition in Europe: Looking Back, Looking Forward. Archaeological Institute of America, Boston: 297-313.

Classen E. 2005. Siedlungsstrukture der Bandkeramik im Rheinland. In J. Lüning, Ch. Frirdich and A. Zimmermann (eds.), Die Bandkeramik im 21. Jahrhundert. Symposium in der Abtei Brauweiler bei Köln vom 16.9.-19.9.2002. Internationale Archäologie. Arbeitsgemeinschaft, Symposium, Tagung, Kongress. Marie Leidorf $\mathrm{GmbH}$, Rahden/ Westf.: 113-124.

Coudart A. 1998. Architecture et société néolithique. L'unité et la variance de la maison danubienne. Maison des sciences de l'Hommeś. Paris. 
Čižmář Z. 1998. Nástin relativní chronologie lineární keramiky na Moravě - Outline of the relative chronology of the Linear Pottery at Moravia. Acta Musei Moraviae, Sci. Soc. 83: 105-139.

Delage C. 2004. Beyond Past Cultural Geography: Example of the Levantine Late Palaleolithic. In C. Delage (ed.), The Last Hunters-Gatherer Societies in the Near East. John and Erica Hedges, BAR IS 1320. Archaeopress, Oxford: $95-117$.

Frirdich Ch. 2005. Struktur und Dynamik der bandkeramischen Landnahme. In J. Lüning (ed.), Die Bandkeramiker. Erste Steinzeitbauern in Deutschland. Bilder einer Ausstellung beim Hessentag in Heppenheim/Bergstraße im Juni 2004. Verein Bandkeramisches Aktionsmuseum e.V.. Marie Leidorf GmbH, Rahden/Westf.: 81-109.

Hachem L. 1994. Structuration spatiale d'un village du rubanée récent, Cuiry-lès-Chaudardes (Aisne). Analyse d'un catégorie de rejets domestiques: la faune. In S. Auxiette, L. Hachem and B. Robert (ed.), Espaces physiques espaces sociaux dans l'analyse interne des sites du Néolithique a l'Age du Fer. 119e congrés CTHS. Éditions du CTHS, Amiens: 245-261.

Halstead P. 1999. Neighbours from Hell? The Households in Neolithic Greece. In P. Halstead (ed.), Neolithic Society in Greece. Sheffield Academic Press, Sheffield: 77-95.

Kaczanowska M., Kozłowski J. K. 2003. Origins of the Linear Pottery Complex and the Neolithic Transition in Central Europe. In A. J. Ammerman, P. Biagi (eds.), The Widening Harvest. The Neolithic Transition in Europe: Looking Back, Looking Forward. Archaeological Institute of America, Boston: 227-248.

Kneipp J. 1998. Bandkeramik zwischen Rhein, Weser und Main. Studien zu Stil und Chronologie der Keramik. Universitätsforschungen zur prähistorischen Archäologie 47. Rudolf Habelt. Bonn.

Kuijt I. 2000. Near Eastern Neolithic Research: Directions and Trends. In I. Kuijt (ed.), Life in Neolithic Farming Communities. Social Organization, Identity, and Differentiation. Kluwer/Plenum, New York at al.: 311-322.

Lüning J. 2005. Bandkeramische Hofplätze und absolute Chronologie der Bandkeramik. In J. Lüning, Ch. Frirdich and A. Zimmermann (eds.), Die Bandkeramik im 21. Jahrhundert. Symposium in der Abtei Brauweiler bei Köln vom 16.9.-19.9.2002. Internationale Archäologie. Arbeitsgemeinschaft, Symposium, Tagung, Kongress. Marie Leidorf $\mathrm{GmbH}$, Rahden/Westf.: 49-74.

Mateiciucová I., Małecka-Kukawka J. 2007. Worked Stone: Obsidian and Flint. In A. Whittle (ed.), The Early Neoli- thic on the Great Hungarian Plain. Investigations of the Körös culture site of Ecsegfalva 3, County Békés. Varia Archaeologica Hungarica 21. Archaeological Institute of the Hungarian Academy of Sciences, Budapest: 677-726.

Modderman P. J. R. 1986. On the typology of the houseplans and their European setting. Památky archeologické 77: 383-394.

Nowak M. 2009. Hunter-Gatherers and Early Ceramics in Poland. In Jordan P., M. Zvelebil (ed.), Ceramics before Farming. The Dispersal of Pottery Among Prehistoric Eurasian Hunter-Gatherers. Left Coast Press, Walnut Creek: 449-476.

Pavlů I. 2005. Počátky antropogenní činnosti v Podoubraví. The beginnings of antropogenic activities in the rever Doubrava flood plain. In Pavlů I. (ed.), Bylany Varia 3. Archeologický ústav Akademie věd České republiky, Praha: 55-92.

2011. Společnost na neolitickém sídlišti Bylany. Status a role artefaktu. Society on a Neolithic Site of Bylany. Status and Role of Artefacts. Archeologický ústav Akademie věd České republiky. Praha: electronic edition (CD).

Pavlů I., Květina P. 2008. Die kulturelle Entwicklung in Böhmen am Ende des 6. Jahrtausends v. Chr. In A. ZeebLanz (ed.), Krisen - Kulturwandel - Kontinuitäten. Zum Ende der Bandkeramik in Mitteleuropa. Internationale Archäologie. Arbeitsgemeinschaft, Symposium, Tagung, Kongress 10. M. Leidorf, Rahden/Westf.: 275-302.

Pavlů I., Rulf J. 1996. Nejstarší zemědělci na Kutnohorsku a Čáslavsku. Archeologické rozhledy 48: 643-673.

Perlés C. 2001. The Early Neolithic in Greece. Cambridge University Press. Cambridge.

Petrasch J. 2003. Zentrale Orte in der Bandkeramik. In J. Eckert, U. Eisenhauer and A. Zimmermann (eds.), Archäologische Perspektiven: Analysen und Interpretationen im Wandel. Festschrift für Jens Lüning zum 65. Geburtstag. Internationale Archäologie. Studia Honoraria 20. Verlag Marie Leidorf GmbH, Rahden/Westf.: 505- 514.

Price T. D., Bentley R. A. 2005. Human Mobility in the Linearbandkeramik: An Archaeometric Approach. In J. Lüning (ed.), Die Bandkeramiker. Erste Steinzeitbauern in Deutschland. Verein Bandkeramisches Aktionsmuseum e.V. Marie Leidorf GmbH, Rahden/Westf.: 203- 216.

Runnels C. 1989. Trade Model in the Study of Agricultural Origins and Dispersals. Journal of Mediterranean Archaeology 2(1): 149-156. 
Stehli P. 1988. Zeitliche Gliederung der Verzierten Keramik. In U. Boelicke, D. v. Brandt, J. Lüning, P. Stehli and A. Zimmermann (eds.), Der bandkeramische Siedlungsplatz Langweiler 8, Gemeinde Aldenhoven, Kreis Düren. 2 Bände. Rheinische Ausgrabungen, Bd. 28. Beiträge zur neolithischen Besiedlung der Aldenhovener Platte, 3. Rheinland-Verlag, Köln: 441-482.

Stäuble H. 2005. Häuser und absolute Datierung der Ältesten Bandkeramik. Universitätsforschungen zur prähistorischen Archäologie 117. Rudolf Habelt. Bonn.

Soudský B. 1966. Bylany, osada nejstarších zemědělců mladši doby kamenné. Academia. Praha.

Šída P. 2007. Využívání kamenné suroviny v mladši a pozdni době kamenné. Dílenské areály v oblasti horniho Pojizerí. The use of stone raw materials in the Neolithic and Eneolithic. Dissertationes Archaeologicae Brunenses/Pragensesque. Praha-Brno.

Tangri D. 1989. On Trade and Assimilation in European Agricultural Origins. Journal of Mediterranean Archaeo$\operatorname{logy} 2(1): 139-148$.

Van de Velde P. 1979. On Bandkeramik social structure: an analysis of pot decoration and hut distribution from the Central European Neolithic communities of Elsloo and Hienheim. Analecta Praehistorica Leidensia 12. University Press Leiden.

1990. Bandkeramik social inequality - a case study. Germania 68: 19-38.

2007. The Bandkeramik settlement. Analecta Praehistorica Leidensia 39: 223-244.
Vencl S. 1982. K otázce zániku sběračsko-loveckých kultur. Problematika vztahů mesolitu vůči neolitu a postmesolitických kořistníků vůči mladším pravěkým kulturám. To the question of the end of gathering-hunting cutures. Archeologické rozhledy 34: 648-694.

2007. Mladý paleolit. Later Paleolithic. In S. Vencl (ed.), J. Fridrich. Archeologie pravěkých Čech 2. Paleolit a mezolit. Archeologický ústav Akademie věd, Praha: 50103.

Verhart L. B. M., Wansleeben M. 1997. Waste and prestige; The Mesolithic-Neolithic transition in the Netherlands from a social perspective. Analecta Prehistoria Leidensia 29: $65-73$.

Verhoeven M. 1999. An archaeological Ethnography of a Neolithic Community. Space, Place and Social Relations in the Burnt Village at Tell Sabi Abyad, Syria. Nederlands Historisch-Archaeologisch Instituut te Instanbul. Leiden, Nederlands Instituut voor het Nabije Oosten. Istanbul.

Whittle A. 1996. Europe in the Neolithic. The creation of new worlds. Cambridge University Press. Cambridge.

Zápotocká M. 1999. Stvolínky u České Lípy. První dům kultury s vypíchanou keramikou v Čechách. The first house of the Stroked Pottery culture in Bohemia. Sbornik prací Filozofické fakulty brněnské university 4: 61-71.

Zimmermann A. 1995. Austauschsysteme von Silexartefakten in der Bandkeramik Mitteleuropas. Universitätsforschungen zur prähistorischen Archäologie 26. Habelt. Bonn. 